\title{
'I choose March': Les Kurbas, Avant-garde Berezil and Shakespeare - Review of Irena R. Makaryk's Shakespeare in the Undiscovered Bourn (2004)
}

\author{
Svitlana Shurma
}

Irena R. Makaryk. Shakespeare in the Undiscovered Bourn: Les Kurbas, Ukrainian Modernism, and Early Soviet Cultural Politics. Toronto: Toronto Press Incorporated, 2004. 257 pp. ISBN 0-8020-8849-X.

I choose March,

because it's like a storm, because it's like laughter,

because it has power,

because it's revolution

from which summer is born. (68)

(Kurbas' 1922 adaptation of a Bjørnson poem, translated by Irena Makaryk.)

Ukrainian theatre history is not as wellknown or well-represented in academic theatre studies as is for example Swedish, Polish, or Czech history. Yet, this lack of attention might not be merely the result of simple disinterest in the Eastern-most country in Europe, but the lack of accessible material along with the suppression of information by the dominating Russian discourse. Luckily, the opening of borders after the collapse of the Soviet Union and subsequent access to classified archives behind the former Iron Curtain has led to an increase of scholarly publications related to various cultural phenomena in the republics of the USSR which had been unknown and mostly unexamined in areas both inside and outside the former Iron Curtain. One figure whose works and life certainly deserve to be reexamined in this context or in any other is the reformer of the Ukrainian avant-garde theatre Les Kurbas (1887-1937).

In Shakespeare in the Undiscovered Bourn, Professor of English and interdisciplinary researcher Irena R. Makaryk introduces the reader to the philosophy, artistic approach and scenography of Les Kurbas. Influenced by Bergson, contemporary of Craig, Kurbas founded several of his own renowned assemblages of avant-garde artists and theorists despite the fact that the artist was generally kept in oblivion by the Soviet regime and finally executed in 1937. This book should be of interest not only to theatre historians, but also to general public, as the style of Makaryk's writing and her extensive commentaries on the events and ideas in question portray a broader picture of what was happening in Ukraine from the 1910s to the 1930s. Through Shakespeare and the Shakespearean context, the scholar explains why early $20^{\text {th }}$ century Ukrainian theatre history in general, and Kurbas in particular as one of its leading lights, richly deserve a reevaluation from a modern standpoint. 


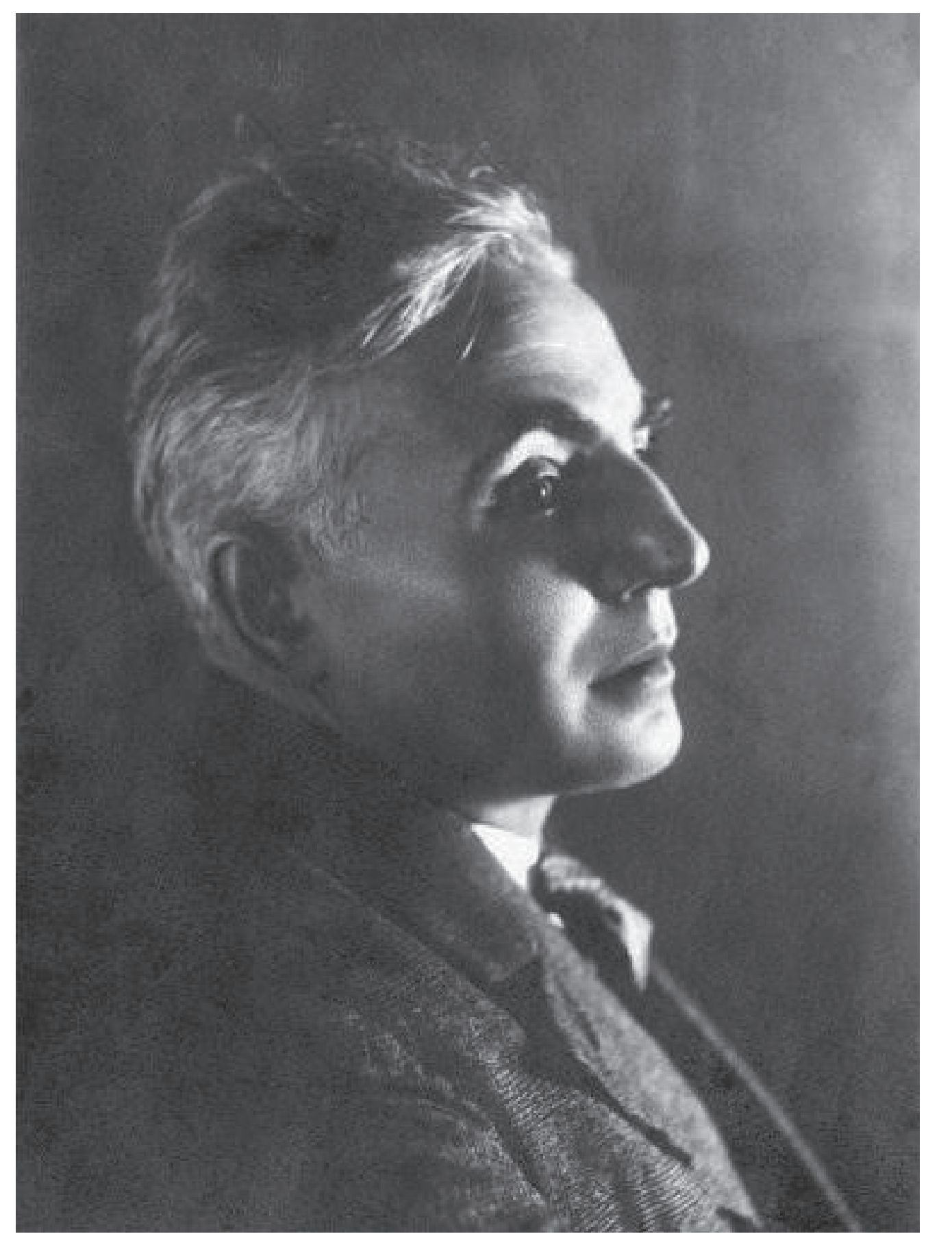

Fig. 1: Oleksandr-Zenon Kurbas (1887-1937) 
The monograph is mainly centered around the 1924 production of Macbeth by Les Kurbas in the Berezil theatre in a staging which turned 'Shakespeare upside down' (3): 'Kurbas had hoped through the 1924 Macbeth to get this audience to imagine a truly liberating cultural and stylistic alternative to inherited and prevailing conventions. Far from attempting to alienate them, he wished to insist upon the audience's share in the play's action; he called for an audience of "co-creating Shakespeares" (111). Unlike some commentators (e.g. KRYZHANIVSKY et al. 2020; FOWLER 2016), who speak of the Berezil in a way often reduced to Kurbas' theatre alone, Makaryk describes Berezil as a movement that attempted to lay the foundations of a theatre school, an aesthetic theory, a new mode of actor and director as well as several other innovations. In fact, the name 'Berezil' is derived from the archaic name of March and was associated with the revolution in Ukraine (68).

This production is rightly considered seminal in both Kurbas' creative development as well as in the overall history of Western theatre (KORNIENKO 2018). In fact, Kurbas' 'estrangement' techniques used for this production preceded what later became known as Brechtian theatre by almost a decade (65). Irena Makaryk's extremely meticulous research includes her own translations of what survived of the archives of Kurbas as well as other members of the Berezil. The author reconstructs the production and performance in fine detail, from props and costumes, acting and choreography, to the preparation for the staging in the context of Kurbas' central role in the Berezil movement. Yet, these events and the 1924 Macbeth itself are not presented in a vacuum: the researcher has outlined the political, social and cultural situation in Ukraine after the October Revolution. Makaryk has provided an account of major influences upon the director that shaped his views and creative approach, e.g. in his earlier experiments, chiefly with Shakespeare. She describes these major tracks of inspiration, including Ukrainian baroque traditions, Bergson's idea of fluid time, Einstein's theory of relativity and several other influences. Along these lines, readers also come to learn about the influence Kurbas had on Meyerhold as well as the rivalry between the two directors. On the pages of Makaryk's book Kurbas appears not just as a national, Soviet or Western master, but an artist who, on the one hand, represented his time and, on the other, transcended it.

To give a reader of today an idea of why Kurbas and the Berezil were so important for the Ukrainian theatre of the time, Makaryk compares the 1924 Macbeth with two other Shakespearean productions, one from 1926 by Panas Saksahansky, a director who continued the traditions of the Ukrainian ethnographical theatre, and one from 1927 by Hnat Yura, whose epigonic Shakespearean production had success neither with public nor critics. Each director in his own way polemized with Kurbas' avantgarde techniques. Makaryk provides numerous socio-cultural details to explain why Saksahansky's and Yura's stagings, though important for the development of Ukrainian theatre, are generally not worthy of study today outside of Ukraine.

The last chapter, which provides an account of Kurbas' final years, including other Shakespearean productions as well as the Ukrainian SSR under Stalinist rule from 1928 to 1939 , i.e. two years after Kurbas' execution, ends the book in 


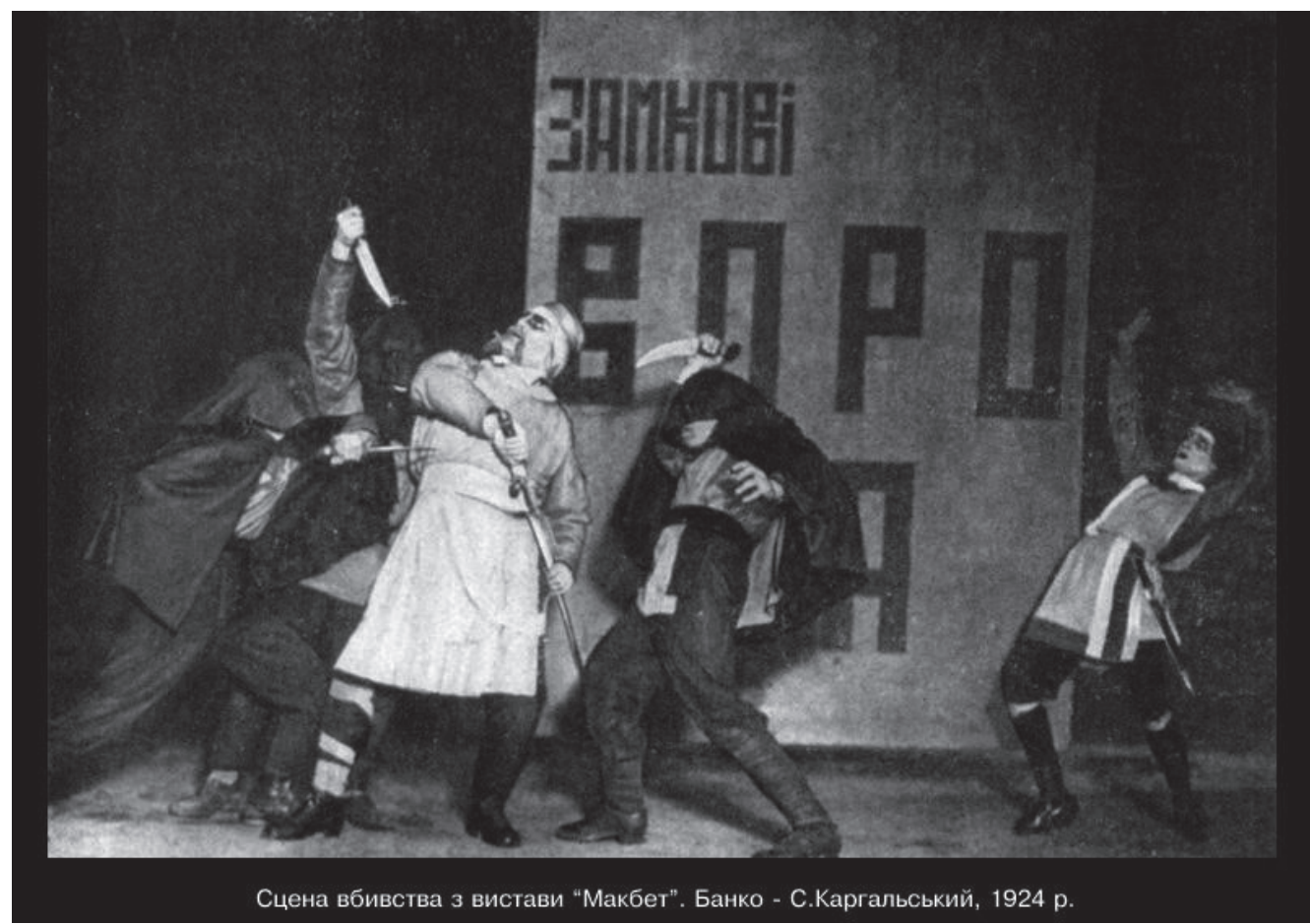

Fig. 2: Murder scene from Macbeth. Banquo - Serhiy Karahalsky, 1924.

Courtesy of the Les' Kurbas Center.

a somewhat rushed and abrupt way compared to the earlier sections. The chapter's chief focus thus becomes the GOSET 1935 production of King Lear starring Solomon Mikhoels, which according to the scholar impressed even the great Craig. Makaryk's description of this production demonstrates how Kurbas' signature style could not be erased even after his arrest in 1933, showing the legacy of the artist and his influence on his peers after his departure.

Only very briefly is the tragic fate of the Ukrainian director after his arrest mentioned. Makaryk concludes the book with a historical perspective: 'Kurbas's fate was emblematic of the fate of non-Russian republics' cultural histories: erased both in the USSR and in the West, which either rep- licated neoimperial discourses or reduced discussion into familiar Marxist categories of class, capitalism, and ideology' (204).

Despite its solid results from active research in independent Ukraine supported by the Les Kurbas Centre as well as Kurbas enthusiasts and researchers around the world, Makaryk's monograph sixteen years after its publication remains the most comprehensive biographical, historical and theatrological account of Kurbas' legacy written in English. Though other English-language books on Ukrainian Soviet theatre (see MAKARYK and TKACZ 2010; FOWLER 2017) place Kurbas in a broader context, a translation of the complete Kurbas archives and a comprehensive, detailed biography of the Ukrainian theatre innovator still await us all. 


\section{Bibliography}

FOWLER, Mayhill C. 2016. Berezil' Theatre (БЕРЕЗІЛЬ). [online]. The Routledge Encyclopedia of Modernism. Taylor and Francis, 2016. [accessed 10.03.2020]. Available online at https://www.rem.routledge.com/articles/ berezil-theater. doi:10.4324/9781135000356REM256-1

FOWLER, Mayhill C. 2017. Beau Monde on Empire's Edge: State and Stage in Soviet Ukraine. Toronto: University of Toronto Press, 2017.

KORNIENKO, Nelly. 2018. Les Kurbas: Teatr XXI Stolittia: Lektsia [Les Kurbas: 21-century
Theater: A Lecture]. Mystetskyi Arsenal, 2018. [accessed 10.03.2020] Available online at https://artarsenal.in.ua/uk/education/ proekt/proekt-les-kurbas-teatr-xxi-stolittyalektsiya-nelli-korniyenko/

KRYZHANIVSKY, Stepan, Ihor STEBELSKY and Lubomir HAJDA et al. 2020. Ukraine [online]. [accessed on 10.03.2020]. Available online at https://www.britannica.com/ place/Ukraine/Music\#ref404835.

MAKARYK, Irena R. and Virlana TKACZ (eds.). 2010. Modernism in Kyiv: Jubilant Experimentation. Toronto/Buffalo/London: University of Toronto Press, 2010. 